\title{
Analysis of Variables for the Suitable Growth of a Latin American City in a Contemporary Context
}

\author{
Oscar Saul Hernandez Barrera, MEng \\ Oscar Montano Arango, PhD \\ Jose Ramon Corona Armenta, PhD \\ Humberto Ivan Navarro Gomez, PhD \\ Israel Aaron Palma Quiroz, PhD \\ Joselito Medina Marin, PhD
}

Instituto de Ciencias Básicas e Ingeniería, Universidad Autónoma del Estado de Hidalgo, Ciudad del Conocimiento, México

\section{doi: 10.19044/esj.2016.v12n17p97 URL:http://dx.doi.org/10.19044/esj.2016.v12n17p97}

\begin{abstract}
Occupation in a city involves the process of continuous expansion. The fitness of a territory can be measured as a result of its physical, socioeconomic, and cultural variables. Hence, this is what lays the foundations for a comprehensive growth of human settlements. Also, it provides a setting that allows the social reproduction of its inhabitants beyond their basic needs. The way to predict its expression in the territory results to elements conceived through planning. This planning is conditional on the existing legal framework, and it is expressed during zoning which is exceeded in many cases. This research analyses the characteristics and practices of the planning process which is derived from various considerations in the international arena. It was conducted from a prospective approach to manage the territory with the aim of identifying variables that allows one to understand the dynamics of the physical expansion and growth of the cities. Also, it also opines success stories in order to define the basic components which are articulated in a harmonious and sustainable way.
\end{abstract}

Keywords: City, Expansion, Growth, Sustainability, Latin America

\section{Introduction}

The increase in the needs of a growing population is a major challenge facing urban conglomerates called cities. This challenge arises due to the attempt to meet the social needs of families with high birth rate. Consequently, various questions about the ability of these urban clusters 
address the phenomenon of globalization (Cabrero, 2013). Thus, its inclusion is currently being conceived.

In the case of Mexico, the phenomenon of migration from rural to urban area is dynamic. Therefore, this highlights the need to respond in a timely manner to the requirements of a growing society (Garza, 2000). As a result, the disposition of urban land has become an element and a fundamental premise during the construction of the city.

However, the physical expansion of Latin American cities reflects the incipient formation of public-policies conceived in some cases partially. It leaves aside the fundamental considerations and allows the cities to forge a system in meeting the development and welfare needs of the community. Many of them promoted by market forces are regarded only as spaces for the production of goods and services. This design limits its capacity since they also serves as places for acquiring knowledge, creation of new ideas, and definition of the social relations. Therefore, this occurs in the cities where there are new forms of citizenship, government, coexistence, mobilization, and human realization (Cabrero, 2013).

In some cases, Latin America has tried to incorporate the concept of urban competitiveness with a divergent and contradictory meaning in some cases. It is adjusted to the national context, and is revalued at the local level. However, this meaning goes beyond its current definition. Competitiveness is a series of processes that together allows the targeting of an integral project of the city (Kennedy, 2007). The entity should provide the minimum essential elements for the development of economic and social activities. These elements include: the influx of knowledge; technological innovation; the development of innovative companies in terms of infrastructure and urban facilities that facilitate such activities; social capital that strengthens cooperation between business groups of social diversity with highly trained human capital; and a dynamic regional sustainability that preserves natural resources and does not deteriorate the environment indiscriminately. Therefore, understanding the process of the formation of these urban conglomerates is not a simple task. Thus, it is required in order to interpret the complex relationships in their formation (Herce, 2005). Its importance lies, among other things, on the fact that they have a statistical record of daily living (birth rate), survival rate, as well as the pace of growth, welfare, and the progress of its inhabitants. In the world today, urban cities are occupied by more than $50 \%$ of the population. In the case of urban areas in Mexico, it is occupied by more than three-fourths of the population of Mexico.

Through this way, the design of public policies should consider cross-cutting elements that are used to achieve a tangible change (Winchester \& Gallicchio, 2003). Also, it allows the foundations within the framework of 
the civil society. This is considered in terms of the best use of their resources both in an economic, political, or social sphere. In this sense, it is necessary to design tools capable of generating information that reliably reflect processes that, at some point, were conceived in the territory. Consequently, it also reflects their impact on the dynamics of cities. However, this allows the decision makers in the different orders of government to acquire more knowledge about the situation of their cities and carry out actions aimed at creating the best conditions to promote development (Crow 2003). In these sectors, the population with greater deficiencies benefited the most.

Therefore, the present study identifies variables that allow an interpretation of the phenomenon of territorial expansion of the cities. Also, it identifies those that are important and transcendental, both nationally and internationally.

\section{The Concept of Development as a Guideline in Territorial Use}

In trying to align the mechanisms in a short term, it is difficult to observe any significant changes that allow optimal use of the territory. Also, it is necessary to lay the groundwork for their permanence in the long term (Boisier, 2007). The new environment for the exploitation of the territory is located in three major scenarios: the shortcut (integrated by the processes of globalization and decentralization), the strategic (linked to a new organization and land management), and the political (with reference to a modern State capable of making territorial driving through different political instruments) (Sesmas, 2011).

Figure 1. Scenarios that defines the territory

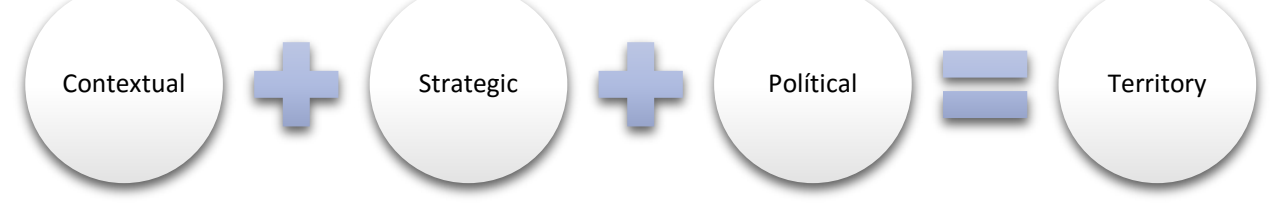

Source: Own, calculations based on Sesmas, 2011

On the other hand, the concept of development also offers different connotations since it is a framework that offers a general guideline. Also, it has a significant impact on the conformation of the territory. In this sense, the economy was the first discipline that used this idea, almost like a synonym for economic growth. Thus, the geographic field acquires social contexts that make it closer to the non-economic needs of the population. Furthermore, development is a set of potential that each social group owns and which must be developed. This etymological interpretation of the concept shows that the progress, the well-being of the population, does not depend mainly on external factors, but rather on endogenous latent potentials waiting to be developed or discovered (Berton, 2009). 
Capabilities is understood as an alternative combinations which someone can engage in or become i.e., the different performances can be achieved (Rojas, Cuadrado \& Fernandez, 2005). Hence, this is the mean similarly which a territory and particularities contains and which should be strengthened. This is aimed at demonstrating a tangible difference that offers an advantage on the eve of a development. In this regard, it is necessary that "if ultimately we consider the development as the expansion of the capacity of the population to be freely chosen and valued, it would be entirely inappropriate to extol human beings as instruments of economic development” (Sen, 1998).

Hall \& Du Gay (2003) mentioned that the construction of utopias was indispensable in the pursuit of development. On the other hand, Tirzo \& Hernandez (2010), Hiernaux (2005), and Kuri (2013) describes that in transition, collective consciousness is fundamental to social consolidation.

Therefore, a fundamental premise is used to define a directive enabling coexistence and socio-economic organization of the space within a broader and global structural coherence. Offner (1993) advocates the concept of consistency which states the idea of the structural type-approval within the scope of the relationship between the actors and the territory.

\section{The Latin America City}

The growth of Latin American cities over time has sampled certain peculiarities characterised by contextual moments. Figure 2 shows the phases of the generalized structural schemes of the urbanization of the city in Latin America. In these phases, the city changes in a compact manner to a sectoral perimeter and from a decentralized to a fragmented City (Borsdorf, 2003).

Figure 2. Model of structural development of the Latin American city

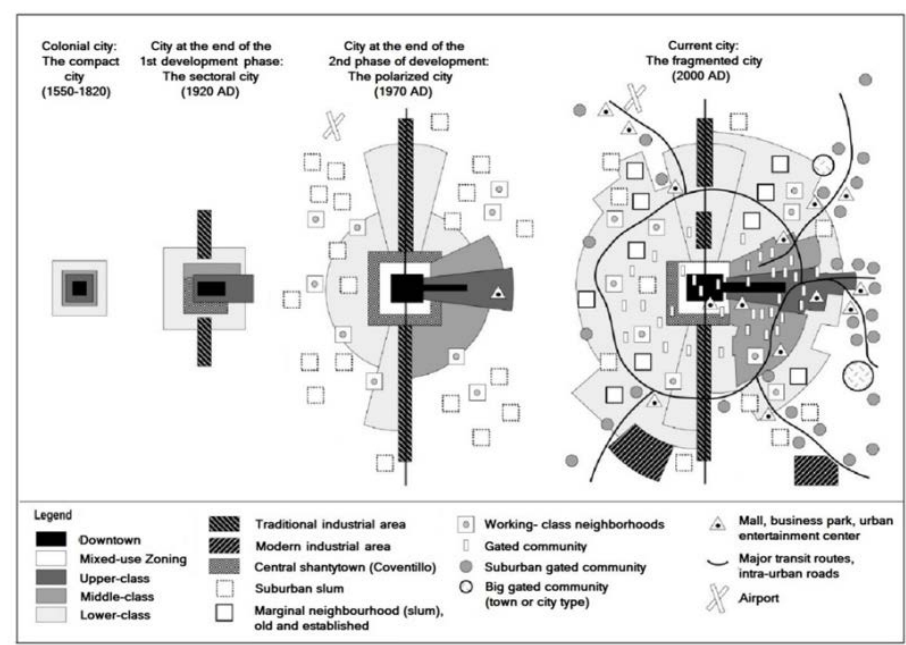

Source: calculations based on Borsdorf, 2003. 
In the last phase, the influence of globalization has developed dramatic changes based on the structure of the cities and on urban development (Hidalgo \& Borsdorf, 2005). As a result, this has made it to expand the traditional model of urban development of the cities of Latin America by establishing new phases (Borsdorf, Bahr \& Janoschka, 2002; Borsdorf, 2003; Bahr \& Borsdorf, 2005). In Europe, new ways of overcoming distances (highways, subway system and extension of the Metropolitan railways) are also a basic condition (Avellaneda \& Lazo, 2011). Furthermore, this is in addition to generating changes in the ways of life and new demands on the environment. Also in Latin America, urban growth had a new dimension. This was in the sense that the peripheral areas of large cities became more dynamic than the central areas of the cities.

Hidalgo and Borsdorf (2009) explain that the results are very different in many countries of Western Europe. Also, the growing suburbanization and evolution of these trends in Latin America are still very difficult to determine. According to Escolano and Ortiz (2005), Latin America is in a phase of suburbanization. Subsequently, the new residential areas and the new industrial and commercial centres are within the administrative limits of the city. This, however, has a close functional relationship with the centre of the city.

In this sense, it can be inferred that the territories are dynamic. They are strengthened by the relationships that are reciprocal. Here, the new conditions are not added to the pre-existing one, but they interact with them; also, they are adjusted and modified in the form of mutual determination (Pudup, 1988). Additionally, the territorial expression is a manifestation of the Exchange and the product of the intricate internal and external relations. Through understanding, we can be able to generate new forms of appropriation of space and reduce disparities through a homogeneous growth. During this process, the impact of stakeholders can be felt in a streamlined way. Also, the decision making process will become effective.

In the context of Mexican cities, the manifestation of the phenomenon of Metropolis requires a new development in the urban conglomerates. This results to a double impact and the conformation of peripheries with adverse characteristics in a widespread manner. Furthermore, this leads to an increased dependence on the supply of resources from the outside with incidence on an international scale, as well as the significant increase in displacement flows. Also, internal character with impact on the reconfiguration of the urban centres, in its transit to the outsourcing of the economy, results to a mismatch between the demand for space, urban infrastructure, and the supply of such elements (Bazant, 2010). This triggers a lack of requirements of the population. It also result to a 
growth crisis whose consequences have an impact in terms of the quality of life (QoL).

The idea of periphery (Rodríguez, 2011) refers to an important change in its significance in urban theory that is synthesized in a loss of rental value. Thus, it is a substantive transformation that articulates a double loss of the value of the place in terms of:

\section{-} decisive);

Locational independence (the territorial situation is no longer

- $\quad$ Loss of functional value for the city and the metropolis.

Therefore, the differentiation of the localization of applications in the urban structure of the Mexican cities follows a pattern of horizontal growth (Aguilar \& Mateos, 2011). Therefore, this is with the respective costs that it represents. In a conceptual manner, Figure 3 reflects that the form of exploitation of the territory, which certainly follows the trajectory of the cities of Latin America on a larger scale (Hidalgo \& Borsdorf, 2009).

Figure 3. Model of urban structure of Mexican cities
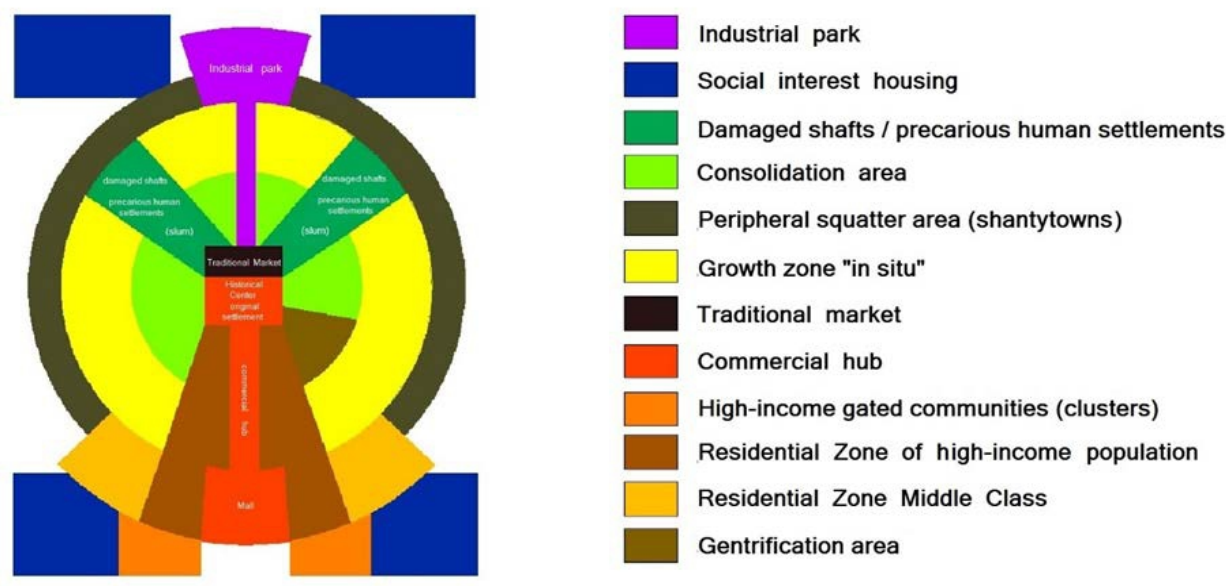

Source: Adapted from Aguilar \& Mateos, 2011.

Baigorri (1995) emphasizes a very recurrent phenomenon, which is the progressive transformation of the rural-space in urban-space. Therefore, this coexists with a variety of land uses. In addition, it distinguishes two broad categories that are complementary and mutually exclusive to one another. Free or public spaces include the road network, parks, gardens, the urban spaces, and the built spaces. Thus, the ground which is vacant later becomes the space of the private domain. Although some of the buildings will be the equipment of community which usually have public ownership. In this way, the use of public spaces and segmented spaces were conformed to urban morphology (Vilagrasa, 1991). Pértile (2012), on his website, 
mentions that three aspects should be considered: the form of the urban network, the type of buildings in this network, and the land uses.

\section{A Territorial Approach beyond Latin America}

Our common future established as part of the worldwide lexicon is the concept of "sustainability" and "sustainable" as a tool for development. However, different currents which are manifested, in particular, in human settlements have been developed. The international referents allude to three approaches to growth: intelligent, new urbanism, and environmentally friendly (Brundland Report, 1987). Smart growth and new urbanism have been adopted in the United States. This is with regards to recognition and integration in planning, development goals, and urban policies.

The approach to green growth is less influential in the U.S. (Saunders, 1997). However, in other parts of world, it has been received with much interest as an approach for developing urban areas, in particular Europe, Canada, Australia, and New Zealand (Edwards \& Jepson, 2010). In addition, the development also occurs in a contemporary way in Asia (Tabet, 2014).

In general, smart growth is understood as an attempt to stop the expansion. However, his physical expression is comprehensive and addresses issues such as the protection of natural resources and the diversity of housing. In this case, economic development is based on local capacity and the citizen's participation (Gavinha \& Sui, 2003).

On the other hand, the new urbanism is a design that represents an architecture of community, and which is more humanized in the scale and character (Godschalk, 2004). With a focus on the physical appearance and layout of the district to improve the quality of life, it is composed of mixed uses and one configuration which is more compact with a consistent and responsive architecture to the place (Katz, 1994); abundant common open space (at the same time functional and natural); and internal circulation with a friendly and oriented pedestrian (Wheeler, 2004).

New Urbanism has a strong interest in the United States known as Congress for the new urbanism. Its members are planners, developers, architects, engineers, government officials, investors, and activists of the community, as well as people who are interested. Through the "cannons" that have been formalized, new urbanism is defined as the search for "the restoration of coherent metropolitan regions within existing urban centres and conservation of natural environments". Consequently, this occurs all through the planning and design process based on the citizen's participation, specifically its equivalence with "sustainability". The objective is the development of communities that do not exceed the limits of the nature of their livelihood, i.e. their carrying capacity. 
Green-growth seeks the creation of eco-city, in terms of policies of land use, which maximize urban density and transportation options, reduce energy consumption and travel distances, and protect biodiversity (Eco-city Builders, 2014). It also considers the principles as a way to give form and meaning to the concept of sustainability. These approaches identify principles that could materialize to focus on the consolidation of sustainable development, which is of importance to incorporate its features when it comes to shaping schemes for the management of the territory.

- $\quad$ Balance employment and housing. The proximity in terms of the human system is fundamental in the activities of life and work. This will increase productivity and efficiency and will also reduce the consumption of natural resources and the generation of waste.

- $\quad$ A spatial integration of employment and transportation. It facilitates access to improve systemic connectivity and increase productivity and efficiency among residents of the human system.

- $\quad$ The mixed land use. The increase in proximity and diversity in terms of the provision of interactive opportunities for the residents of a community will result in the reduction of the energy consumption for transport and the improvement of the organization in terms of efficiency.

- Production and local consumption of renewable energies. The development of clean and renewable energy strategies replace energy imports and helps in maintaining a long-term sustainability by matching their growth and development with local authorities and carrying capacity.

- Design and efficient construction. The construction of buildings under energy efficiency guidelines will protect against the effects of the depletion of resources.

- $\quad$ Pedestrian and cycling access to work and leisure activities. The nonmotorized transport will reduce energy consumption and protect against resource depletion and pollution. Thus, this is in addition to having positive impacts on the health of the inhabitants.

- $\quad$ Accessibility to housing for all. Homelessness is a manifestation of lack of empowerment among some residents of the Community (like actors in a system). The provision of adequate shelter for all income groups will help to protect against social dysfunction.

- $\quad$ Diversity of housing (style, type, and tenure). Sustainable systems are marked by the diversity of actors and the interactions that are conceived. A diversity of urban image will encourage interactions between people.

- Construction of higher density housing. A more compact development is to reduce the pressure of development in open space. However, this element is essential for the biological and agricultural resource 
necessary for the preservation of the human community and the human system in general.

- $\quad$ Protection of the functions of natural and biological processes. Due to the dependence of nature, the sustainability of the human system requires the maintainability of the integrity of natural systems.

- Participation and empowerment of residents. Increase among residents of a neighbourhood organization's ability to identify and respond to changing conditions.

- $\quad$ Social environments (public spaces for recreation). Increase social contact between the residents of a community to improve the capacity of the community in the Organization and response to changing conditions.

- $\quad$ Sense of place. Increases adherence to the place, the propensity to meaningful participation and interaction, which improves the ability of a community to organize and respond to changing conditions.

- Intermodal transport connectivity. Joint efficiency (a) creates the opportunity for an increased frequency of interactions between the residents of a community, and (b) it reduces dependence on polluting vehicles and high energy consumption.

Consequently, a city where it is allowed "to satisfy the needs of the present without endangering the ability of future generations to meet their own needs” corresponds to the definition exposed in Agenda 21. This is with some variations on other agendas and summits in order to understand the role of cities in the Millennium Development Goals. Therefore, these goals include:

- $\quad$ Promote the recovery of the city,

- $\quad$ Controlling urban sprawl,

- $\quad$ Develop a sustainable management of resources and waste,

- $\quad$ Promote the protection of the natural and cultural heritage,

- $\quad$ Improving the accessibility and efficiency of transport; among others.

Also, in order to support the development of sustainable cities and to assess their performance, a set of indicator-based monitoring systems was generated. In this context, indicators are tools employed to obtain a better and a more accurate results. Moreover, indicators are the key elements for the development of a sustainable planning of cities. It allows one to carry out the assessments of the result of different policies implemented. Therefore, some indicators to be considered are as follows:

- Urban competitiveness levels,

- Importance of services and industry with high levels of innovation,

- Demographic changes,

- Growth of intermediate cities,

- Growth and concentration Metropolitan (sustainability), 
- Urban-rural declining differentiation,

- Growth of the informal sector,

- Urban governance,

- $\quad$ Climate change and city.

Farias (2012) affirms the need for political will to create monitoring systems based on precise indicators. These indicators were developed in Dongtan in China; Cambridge in England; and in other countries which have become icons of competitive and sustainable development. Also, the European green capitals has been awarded to Stockholm-Sweden in 2010 (Eco-intelligent growth, 2011) and Hamburg-Germany in 2011 (European Commission, 2012).

In general terms, the main characteristics of the winning towns are the different measures taken in the field of:

- Air pollution,

- Transit and road congestion levels,

- Greenhouse gases emissions,

- $\quad$ Solid waste,

- Wastewater.

While sustainable development is presented as something integral with priority in different planning strategies, advances have risen from fragment without the institutional and financial tools to carry them out (Rydin, 2011). In a sustainable city, there must be a lot of effective systems: energy, water, healthcare networks, communication and transportation, as well as a coherent urban development. In this context, the development of a low carbon infrastructure is necessary.

In carrying out various activities in the cities, transport networks require a particular attention. This is because it has a number of elements which include:

- $\quad$ Physical infrastructure of activities,

- Vehicles that allow the transfer,

- $\quad$ Drivers of transport,

- $\quad$ Services that enable the activity to be carried out in a safe manner.

Therefore, an urban transport system is a system that leads from one side to another, or that joins two points in geographic space. At the same time, within this system, there are two types of transport: a) freight, and b) passenger. A sustainable urban transport system is one that carries out the union of different points in the geographical space in the most efficient manner. This is with the aim of tending $\mathrm{CO}_{2}$ emissions to zero. Thus, the system of urban transportation, understood as a system of linkages, is in strict relation with the location of the elements in the league. So, transportation and land use correspond directly. In addition, its constitution, 
at the level of the management of the territory should be reviewed with extreme caution in order to consolidate this concordance.

Depending on the use of soil, different types of activities and transportation needs have been generated. At the same time, the transport system has a strong impact on future land use patterns. This is attributed to a greater availability of access to a system of transportation from a certain location, greater accessibility, and other major applications associated with this accessibility. Thus, it is a cyclical process. This virtuous circle, with ensuing capital gains that it generates, has a balance and limit. Furthermore, when this balance is broken, the land use pattern would begin to change. Also, urban disability cycle would be generated.

To reduce the impacts of adverse transport systems, it is necessary to generate its re-structuring and distribution of the elements in the geographical space. This space needs to link the uses of the soil of the city. The morphology of the growth of Latin American cities, in the middle of the 90's, was of the type "oil slick" (Sabatini, 2001), i.e., in continuous expansion. Nowadays, the trend continues. As stated by Mattos (2007), most of the cities have adopted growth patterns scattered in the territory, and are generating an uncontrolled urbanization.

One of the characteristics of these processes of growth is the lack of a regulation according to the speed of the changes occurring in the city. In the past 30 years, more regulation to generate coherent urban development guidelines has reacted to the changes. This is done by adapting the law to the facts. The new housing developments began to appear in rural areas whose land value was lower. Also, his estate has generated added value. Not to be a supervisory body, beyond than the market itself, the quality of the new developments has a low consideration. Also, it entails setting up new areas of the city with much more precarious than the previous standards.

These new difficulties seem to register in a process of crisis and transformation of a deeper nature. It results from the need to adapt to new social, regional, and national economic conditions, and the new features of urban development (Figueroa, 2005).

\section{The Use of Urban Land in the City}

Consequently, the combination of elements around the formation of a city's urban land has been given particular attention. This is considered since it possesses attributes that differentiate it from any other goods. Also, it makes the determination of its value to be a complex process. Firstly, the dual role of urban land should be considered: a) as a factor of production, indispensable in the process of transformation, for example, as regards space that require the industry, Commerce, and offices; and b) as a basics goods used for housing or recreation (Miller, 2005). This dual role of urban land, 
which is also a scarce resource, leads to competition among potential users of this asset. Precisely, this process of competition is responsible for the determination of the value of the soil. Nevertheless, this process is complicated by the interdependence of potential users (Lopez, 2014; Dillon et al., 2010). Secondly, there are physical characteristics that distinguish the use of production factors soil such as a heterogeneous fixed asset for its location. Thus, these fixed assets are indestructible and divisible.

The public sector also has enormous influence in its value, particularly through two ways. These ways includes the construction of infrastructure and equipment for urban and land use planning. One of the tools used by the public sector in the planning of urban growth is the zoning of land uses (Sonaglio \& Da Silva, 2009).

Land use zoning does not eliminate markets, but only restricts its operation. Therefore, it prevents the process of competition for urban land developed irrationally and has negative effects on the functionality of the city (Castle, 2005). The authorities have, in the theory of the zoning, a valuable tool for planning in order to achieve efficiency within an urban area (Clichevsky, 2014; Espasa et al., 2010; Morales, 2005; De la Barra, 2003; Da Silva et al., 2013).

The soil is a good, weak, basic, and indispensable in the process of the transformation of the actual cities. In relation to its function, soil acquires a value that can be handled by the public or private sector. With the zoning and density of occupation management tool, the public sector can manage soil market, reduce external costs, and generate economies of scale. Therefore, this zoning must always take into account the needs of urban location of uses and economic activities, in order to ensure an efficient and orderly city (Viviescas, 1999).

\section{The Urban Built Environmental and Mobility in Mexico}

Against this background, there are three major actions talking about urban development in cities. The first action aims to formalize a generalized guideline development by giving priority to the potential of the territories without undermining their natural resources. The second action aims to satisfy the needs of the population that lives in them based on offering a series of satisfiers (housing, utilities, infrastructure, equipment, soil, recreational, cultural activities, the care for the environment, the built environment, heritage, among others). The third action entails economic development from the generation of economies of scale and agglomeration which favours the establishment of enterprises, productive investment, and employment generation.

In the case of Latin American cities, in particular Mexico, there are no instruments capable of managing urban sprawl. Consequently, this does 
not mean they lack them, but they are derived from the rise of the institutional action of urban planning in the 70's. Planning actions which are promoted is reflected in plans and programs for urban development. This is attributed to the fact that pioneering initiatives of the system of urban and regional planning that Mexico undertook is part of the national policy of the territory.

While it has been 4 decades since the concern for the growth of human settlements played its concession, latent disparities has been manifested today. This, however, results to little progress towards collective welfare which is based on the improvement of the conditions of life and the rational use of resources. This results to the process of generating the conditions for reversing the social backwardness and economic stagnation that has resulted in inequality and poverty. Also, it identifies a cumulative historical investment both in the network of regional infrastructure as those that exist in cities. This is in addition to the set of private and public equipment which serve as a basic platform of urban development and land use planning. Furthermore, this is under the principle of respect for the natural resources of the entities. Also, it is due to particular interests aside from the instruments of articulation of the territory.

Currently, the model of occupation of the territory in Mexico reflects a broad population dispersion and small towns. It also shows an increasing urban phenomenon based on the urbanization and the super-city situations that have not been resolved. This has important implications in the productive operation, the quality of life of the population, the environment, costs to local governments, the allocation and provision of public services, and the infrastructure and housing facilities. In addition, the expansive growth has brought about insecure land tenure in unsuitable areas. For example, in the State of Hidalgo, the tendency of the expansion of the main urban stains is to the shared land surrounding them (see Figure 4). Therefore, this has permeated the State and the municipal level. Also, a wide speculation of the value of the soil was carried out. 
Figure 4. Urban area and Communal land distribution of the State of Hidalgo, Mexico

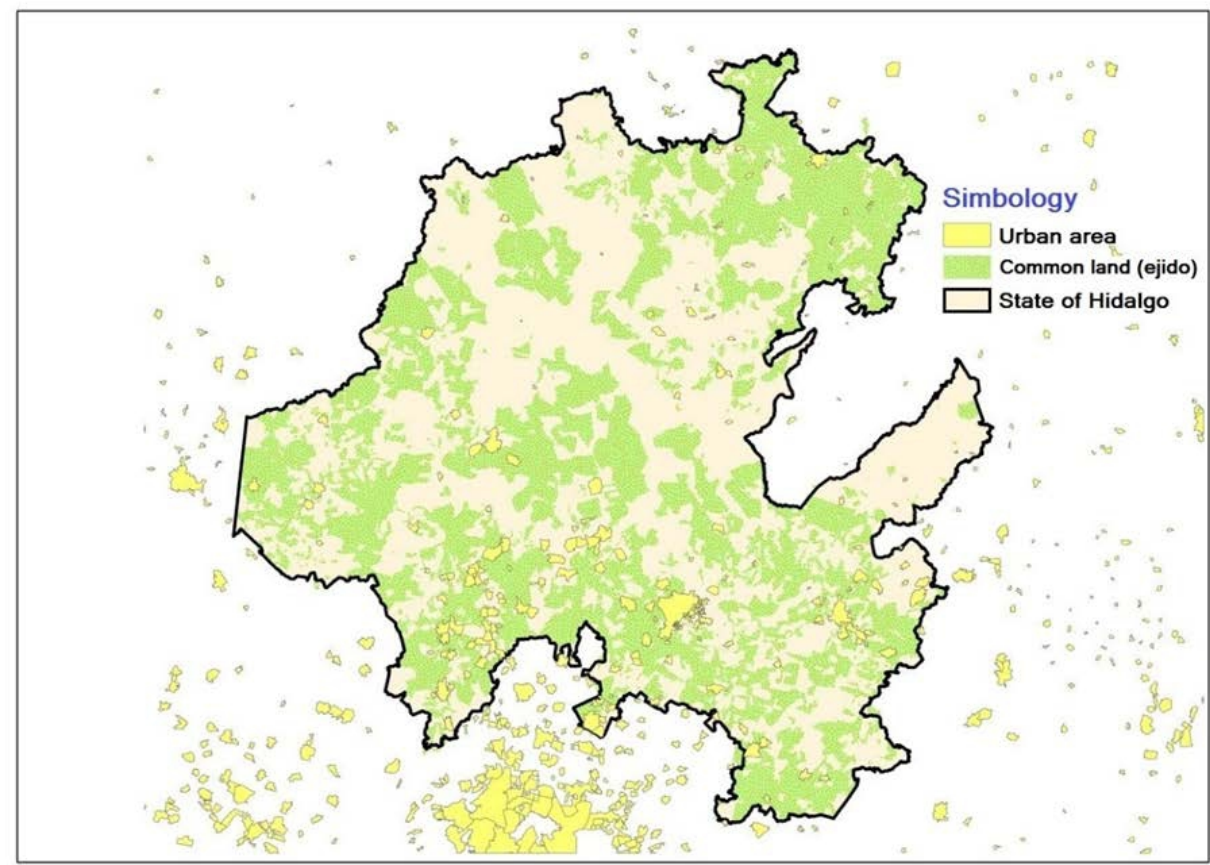

Source: elaboration by us, based on INEGI, 2010 and Gobierno del Estado de Hidalgo, 2014.

A structured planning, proper occupation of the soil, the location of the land use and management of the built environment, and the provision of the needs (goods and services) and requirements of the population centres (cities or conurbations) allows a real exteriorisation of the guideline of the path to follow. Also, it creates strategies and mechanisms of articulation. The integration of local governments is essential in the development of the urban State and Federation.

\section{Conclusion}

In conclusion, there are different approaches around the growth of a city. These growth identify the guidelines and elements that plays a fundamental role in the definition of these urban conglomerates. It also shows the importance of indicators which allow us to make an appropriate assessment of the status of the city. In addition, it also allows us to make a complex relationship between the functional processes and the expansion of human settlements. This, however, reflects the prospective role and sometimes the utopian vision in the long term of what it intends to achieve. However, when talking about Latin America, long-term vision is limited. 
Also, the concept of development results to answers in short-term moments which reconfigure the cities.

At some point, exposed considerations are used to positively address a possible change in the scope and provision of better living conditions. In addition, there are cities that are leaders in sustainability. Therefore, there is a fairly significant stop that separates them from the rest.

It is imperative to redefine a model city to Mexico. This model responds to current needs that involves the issue of the local, State, and federal territories. They can transcend time and can review the legal framework of action. Also, they have an objective and effective vision to transcend the development guidelines in the long term.

Controlling expansion and urban sprawl is an important measure of achieving sustainable urban development. This will generate various social, environmental and economic benefits, as well as reduce the costs of the provision of public services.

Trends in Latin America and the expansion of different urban cities have generated the need to rethink urban public policies to direct efforts towards the transformation of our cities. Therefore, this is done by limiting the horizontal expansion and the privileging of vertical growth.

On the other hand, it must pay special attention to the spatial analysis of the behavior of the variables of employment, transport, housing, and services. Furthermore, the basic premises for the conformation of land use and planning include: the adequacy of the regulatory framework, the importance of the trends, the feasibility of implementation, and deployment as factors of opportunity.

Finally, the actions identified in the exposed approaches will allow the reappraisal of the role of planning and conceptualization to improve strategies for cities. It effectively responds on time to the needs which are designed with a holistic approach, comprehensive, and inclusive. Furthermore, it promotes conditions of equality in terms of access to housing and services. Also, they are capable of being integrated into the global context in which it is immersed.

\section{References:}

Aguilar \& Mateos (2011). Diferenciación sociodemográfica del espacio urbano de la Ciudad de México. EURE, pp. 5-30.

Avellaneda \& Lazo (2011). Aproximación a la movilidad cotidiana en la periferia pobre de dos ciudades latinoamericanas. Los casos de Lima y Santiago de Chile. Transporte y Territorio, 4, 47-58.

Bähr \& Borsdorf (2005). La ciudad latinoamericana. La construcción de un modelo. Vigencia y perspectivas. In: Urbe. Revista de ciudad, urbanismo y paisaje, 2 (2), pp. 207-222. 
Baigorri (1995). De lo rural a lo urbano. V Congreso Español de Sociologia, Granada, España, desarrollado el 28 de septiembre de 1995. Retrieved: http://www.eweb.unex.es/eweb/sociolog/BAIGORRI/papers/rurbano.pdf Bazant (2010). Expansión urbana incontrolada y paradigmas de la planeación urbana. Espacio Abierto, 19 (3), pp. 475-503.

Berton (2009). Apreciaciones conceptuales del término desarollo. Huellas, 13, pp. 192-203.

Boisier (2007). Reseña: Imágenes en el espejo: Aportes a la discusión sobre crecimiento y desarrollo territorial. Ciencias Sociales Online, 4 (2), 183-187. Retrieved: http://www.uvm.cl/csonline/2007_2/pdf/gutierrezresena.pdf

Boudon (1973). Les métodes en sociologie. Paris: Colin.

Borsdorf (2003). Como modelar el desarrollo y la dinámica de la ciudad latinoamericana. EURE, 29 (86), pp. 37-49.

Borsdorf, Bähr \& Janoschka (2002). Die Dynamik stadtstrukturellen Wandels im Modell der lateinamerikanischen Stadt. Geographica Helvetica, 4, pp. 300-310.

Cabrero (2013). Retos a la Competitividad Urbana en México. México: CIDE.

Castillo (2005). Valuación mobiliaria. Integración del uso de suelo a las zonas adyacentes al centro de población. Tesis de maestría, Universidad Autónoma de Nuevo León, México.

Clichevsky (23 de Junio de 2014). Mercado del suelo e informalidad en Ámerica Latina. Retrieved: http://www.cepal.org/pobrezaurbana/docs/cursos/nicaragua/Presentaciones/N ora\%20Clichevsky.pdf

Congress for the new urbanism (2011). Canons of Sustainable Architecture and Urbanism. Retrieved: http://www.cnu.org/canons

Cuervo (Noviembre de 2003). Pensar el territorio. Pensar el territorio: los conceptos de ciudad globlal y región en sus orígenes y evolución. Santiago, Santiago, Chile: ILPES/CEPAL.

Da Silva et al. (2013). Usos de suelo: distribución, análisis y clasificación con SIG. Geografía y Sistemas de Información Geográfica (GEOSIG), pp. 142-152.

De la Barra (2003). Localización de actividades y el mercado Inmobiliario. Revista Urbana, pp. 20-35.

Dillon, Cossio \& Pombo (2010). Valor del suelo urbano en una ciudad intermedia: la volatilidad del capital y sus resultados efímeros. Scripta Nova, Revista eléctronica de geografía y ciencias sociales.

Ecocity Builders (2014). Ecocity Builders. Retrieved: http://www.ecocitybuilders.org/why-ecocities/ 
Eco-inteligencia (4 de Octubre de 2011). ecointeligencia. Retrieved: http://www.ecointeligencia.com/2011/10/estocolmo-referente-desostenibilidad/

Edwars \& Jepson (2010). How Possible is Sustainable Urban Development? An Analysis of Planners' Perceptions about New Urbanism, Smart Growth and the Ecological City, Planning Practice and Resarch, pp. 417-437.

Escolano \& Ortiz (2005). Processus de fragmentation des structures spatiales du Grand Santiago. In: Revue Géographique de l’Est, 3 (4), pp. 195-208.

Espasa, Fittipaldi, \& Michalijos (2010). El mercado de suelo urbano y su incidencia en la configuración urbana. Estudio de caso: ciudad de Monte Hermoso. Huellas, 163-182.

European Commission (27 de Agosto de 2012). European green capital. Retrieved: http://ec.europa.eu/environment/europeangreencapital/winningcities/2011-hamburg/

Figueroa (2005). Transporte urbano y globalización. Políticas y efectos en América Latina. Eure, pp. 41-53.

Garza (2000). Superconcentración, crisis y globalización del sector industrial, 1930-1998. La Ciudad de México en el fin del segundo milenio, pp. 170-177.

Gavinha \& Sui (2003). Crecimiento inteligente. Breve historia de un concepto de moda en norteamérica, Scripta Nova. Revista Electrónica de Geografía y Ciencias Sociales, 7 (146), pp. s/n. Retrieved: <http://www.ub.edu/geocrit/sn/sn-146(039).htm.

Gobierno del Estado de Hidalgo (2014). Anteproyecto del Programa Estatal de Desarrollo Urbano y Ordenamiento Territorial del Estado de Hidalgo. Secretaría de Obras Públicas y Ordenamiento Territorial, Pachuca, Hidalgo. Godschalk (2004). Land use planning challengues. Journal of the America Llanning Association, pp. 5-13.

Hall \& Du Gay (2003). Cuestiones de identidad cultural. Madrid: Amorrortu. Herce (2005). Urbanización, precios del suelo y modelo territorial: la evolución reciente del área metropolitana de Barcela. EURE, pp. 35-51.

Hidalgo \& Borsdorf (2005). La exclusión residencial y el desarrollo de la ciudad moderna en América Latina: De la polarización a la fragmentación. El caso de Santiago de Chile. Geographicalia, 48, pp. 5-29.

Hidalgo \& Borsdorf (2009). El crecimiento urbano en Europa: conceptos, tendencias y marco comparativo para el área metropolitana de Santiago de Chile. Estudios Geográficos, 70 (266), 181-203.

Hiernaux (2005). Identidades móviles o movilidad sin identidad? El individuo moderno en transformación. Revista de Geografía Norte Grande, pp. 5-17.

INEGI (2010). Cartografía geoestadística urbana, Cierre del Censo de Población y Vivienda 2010. Retrieved: 
http://buscador.inegi.org.mx/search?requiredfields=cve_titgen:3604\&client= ProductosR\&proxystylesheet $=$ ProductosR $\&$ num $=10$ \&getfields $=* \&$ sort $=$ met a:edicion:D:E:::D\&entsp=a_inegi_politica_p72\&lr=lang_es\%7Clang_en\&o $\mathrm{e}=\mathrm{UTF}-8 \& \mathrm{ie}=\mathrm{UTF}-$

8\&entqr $=3 \&$ filter $=0 \&$ site=ProductosBuscador $\&$ tlen=260\&ulang=es\&ip $=10$. 210.100.253\&access=p\&entqrm=0\&ud=1\&q=+inmeta:Entidad\%3DHidalgo \&dnavs=inmeta:Entidad\%3DHidalgo

Katz (1994). The New Urbanism: Toward an Architecture of Community. New York: McGraw-Hill.

Kennedy (2007). From Advocacy Planning to Transformative Community Planning in Progressive Planning. The Magazine of Planners Network, pp. 24-27.

Kuri (2013). Representaciones y significados en la relación espaciosociedad: una reflexión teórica. Sociológica, pp. 69-98.

López (21 de Febrero de 2014). Diferencia entre suelo urbano consolidado y suelo urbano no consolidado. Retrieved: http://lopezabogados.org/web/diferencia-entre-suelo-urbano-consolidado-ysuelo-urbano-no-consolidado/

Mattos (2007). Globalización, negocios inmobiliarios y transformación urbana. Nueva Sociedad, pp. 82-96.

Moliner (30 de Junio de 2005). Ciudades para el futuro más sostenible. Obtenido de Notas para entender el mercado inmobiliario. Retrieved: http://habitat.aq.upm.es/boletin/n29/afram.html

Morales (15 de Junio de 2005). Suelo Urbano. Obtenido de Algunas peculiaridades del mercado de suelo urbano. Retrieved: http://nute.ufsc.br/moodle/biblioteca_virtual/admin/files/bibliot._partic._aula 2_\%5Ba\%5D.pdf

Offner (1993). Les effects structurants du transport: mythe politique, mystification scientifique. L`space géografique, 3, pp. 233-242.

Pértile (2012). Morfología Urbana: los planos de las ciudades. Revista geográfica digital, 9 (18), pp. 1-44.

Pudup (1988). Arguments within regional geography. Progress in Human, pp. 369-390.

Rodríguez (2011). Planificación urbana en perspectiva: una mirada a nuestra formación en teoría de la planificación urbana. Quivera, pp. 232-258.

Rojas, Cuadrado \& Fernández (2005). Gobernar las Metrópolis. Washington:

Banco Interamericano de Desarrollo.

Rydin (2011). The purpose of planning. London: University College London. Sabatini (2001). "Segregación residencial en las principales ciudades chilenas: tendencias de las tres últimas décadas y posibles cursos de acción. EURE, pp. 21-42. 
Saunders (1997). Ecology and community design, in: M. Roseland. Eco-city Dimensions, pp. 113-124.

Sen (1998). Etica y desarrollo: la relación. Buenos Aires: BID.

Sesmas (2011). Crecimiento económico y desarrollo social: una contribución al estudio del territorio. Sociedad y Territorio, pp. 265-271.

Sonaglio \& Da Silva (2009). Zonificación, ocupación y uso de suelo por medio del SIG, Estudios y perspectivas en turismo, pp. 381-399.

Tabet (2014). How smart can our cities be?, ARUP, 1 (1), p. 5-6. Retrieved: http://publications.arup.com/Publications/A/At4_magazine/At4_Magazine_I ssue_1.aspx

Tirzo \& Hernández (2010). Relaciones interculturales, interculturalidad y multiculturalismo; teorías, conceptos, actores y referencias, Cuicuilco, 17 (48), pp. 11-34.

Vilagrasa (1991). El estudio de la morfología urbana: una aproximación, Geocrítica, XVI (92).

Viviescas (1999). La ciudad colombiana o del urbanismo en busca del pensamiento (notas para una investigación necesaria), Revista de estudios sociales, pp. 71-79.

Wheeler (2004). Planning for Sustainability. New York: Routledge New York.

Winchester \& Gallicchio (2003). Territorio Local y Desarrollo. Experiencias en Chile y Uruguay. Santiago de Chile: Colección Estudios Sociales. 